\title{
Um sultão no reino das coisas
}

Lucia Helena

Não há dúvida: existe uma secreta conexão entre a medida dos bens e a medida da vida.*

As idéias se relacionam com as coisas como as constelações com as estrelas. 0 que quer dizer, antes de mais nada, que as idéias nem são os conceitos dessas coisas, nem as suas leis. *
- (Benjamin, Walter. "Conselho fiscal". Em: Rua de mão única. Obras escolhidas II. 2a. ed. Trad. Rubens Rodrigues Torres Filho e José Carlos Martins Barbosa. São Paulo: Brasiliense, 1987: 61.)

(Benjamin, Walter. Origem do drama barroco alemão. Trad., apresentação e notas de Sérgio Paulo Rouanet. São Paulo: Brasiliense, 1984: 56.)

Neste começo de século, é notável a forte presença da obra de Walter Benjamin, cuja vida se extinguiu em 1940, em meio à destruição do holocausto. Inúmeros livros sobre o autor têm sido publicados ultimamente, e ele, ao que parece, penetrou com honras o céu da nova era, sobrevivendo ao alvorecer do XXI.

A que se deve este interesse? Não é segredo para ninguém que a fisionomia do mundo se redesenha, hoje, diante do nariz do mais distraído e alienado dos seres.

No universo da globalização e das saudações ao estudo das diferenças, das minorias, do apogeu da homenagem ao excluído, nunca se excluiu tantos, e tão rapidamente, diante de nossos olhos de retinas mais do que fatigadas desse espetáculo voraz e contundente. A mídia e a informática estão aí, para encurtar distâncias, e nunca estivemos tão próximos da indiferença.

Assim, torna-se mais do que oportuno refletir sobre Benjamin e o legado que ele nos deixou. E que, tanto pela atualidade e qualidade dos temas e discussões quanto por seu estado de projeto não concluído (afinal, morreu antes de terminar o anunciado Livro das passagens), convoca a interferência ativa do leitor, provocando-Ihe o interrogar, num tempo de letargia do pensamento.

Acredito que as análises de Benjamin, seu método, sua forma hábil de entrever vínculos entre o que parece tão disperso, sua capacidade de perceber e revelar as estreitas relações entre a matéria bruta e o imaginário da produção de bens de consumo ou mesmo, dizendo de forma mais singela, sua acuidade de examinar, como poucos, a relação entre a arte e a sociedade são algo de inestimável valor. 
(Ibid.: 50.)

(Gagnebin, Jeanne-Marie. "Baudelaire, Benjamin e o moderno". Em: Sete aulas sobre linguagem, memória e história. Rio de Janeiro: Imago, 1997: 141.)

(Benjamin, Walter. Origem do drama barroco alemão. Op. cit.: 50.)

(Ibid.)

(Ibid.)
Quando os Estudos Culturais se dizem, no Brasil, devedores do empenho inglês e norte-americano, e caímos "de boca" nesta nova moda, é oportuno retornar a uma proposta que ainda resta por desenvolver em face dos novos impactos que a sociedade contemporânea oferece, e da qual Benjamin e Adorno foram arquitetos inaugurais.

Ao longo de nosso texto, retomaremos algumas de suas imagens dialéticas - a história, o tempo, a alegoria e a melancolia - e as comentaremos a partir do exame de três de seus mais conhecidos textos, com o objetivo de melhor compreender a forma através da qual Benjamin desenhou sua sutil "dialética do olhar", procurando refletir sobre a atualidade de seu pensamento e a oportunidade de retomá-lo nos dias que correm.

Ao examinarmos o que escreveu sobre Baudelaire, o drama barroco alemão, a Berlim de Weimar, ou mesmo ao consultar as notações biográficas de seu diário de Moscou, tão diversos quanto ao tema, o tempo e o espaço de que tratam, torna-se quase impossível não recordar uma de suas acuradas considerações acerca do que acredita ser a tarefa do pensamento crítico. Se a filosofia, diz ele, quiser permanecer fiel à lei de sua forma como representação da verdade e não como guia do conhecimento, deve-se atribuir importância ao exercício dessa forma, e não à sua antecipação como sistema*. É crucial para ele, quer trate da modernidade, quer retorne ao século XVII, "elucidar as ligações essenciais entre a escrita e a consciência do tempo ${ }^{\prime \prime *}$. Em todas as épocas que tiveram a faculdade de compreender 0 modo de ser indefinível da verdade, esse exercício se impôs. Segundo Benjamin, este tipo de reflexão, a única que the interessa, diga-se de passagem, assume a forma de uma propedêutica. E pode ser designada pelo nome escolástico do tratado*. Seu método é um caminho indireto, que se desvia dos instrumentos coercitivos da demonstração. Há uma renúncia à intenção a priori e, "[i]ncansável, o pensamento começa sempre de novo, e volta sempre, minuciosamente, às próprias coisas. Esse fôlego infatigável é a mais autêntica forma de ser da contemplação ${ }^{\prime \prime *}$. Ao considerar um mesmo objeto nos vários estratos de sua significação, ele não teme interromper o fluxo, construir em mosaico, "na fragmentação caprichosa de suas partículas".*

A presença desse ruminar constante faz com que, na forma ensaística benjaminiana, o diverso se articule num outro tipo 
de prosa, a do tratado, cuja ordenação tem luz e organização muito próprias. Seu objetivo não é nem arrebatar o leitor, nem entusiasmá-lo. Longe disso, Benjamin quer pensar como quem escreve, forçando paradas e recomeços, induzindo o leitor a deter-se para consagrar-se à reflexão. Suas idéias surgem como se fossem mônadas e, numa estrutura cara aos barrocos, elas se dispersam e recolhem o tempo todo. Como no conhecido soneto de Gregório de Matos $^{1}$, em que a vaidade é planta, é rosa, é nau - e uma sendo a outra, numa teoria incessante de correspondências -, o disperso, o fragmentário e o detalhe remetem uns aos outros e ao uno, ao recolhimento que os ata, para novas e sucessivas dilatações de sentido.

Deste modo, não é exagero dizer que o seu pensamento está em constante contemplação e, do mesmo modo, em constante metamorfose. Mas esta é uma mutação que se dá na forma da repetição de cristais que retornam. Tanto o mosaico quanto a contemplação nela justapõem elementos isolados e heterogêneos. Nesse novo habitat, as idéias ricocheteiam numa velocidade impressionante. Assim também ocorre com as inúmeras citações que, leitor voraz, cuidadosamente recolhia, com a paixão do alegorista e do colecionador, sultão das coisas, seduzido pela multiplicidade de chances de produção de sentido a partir de uma relação sempre singularíssima entre a parte e o todo.

Seu trabalho tem tal composição e tão tramada sintaxe que não se pode apreendê-lo apenas no traçado do conjunto e, menos ainda, no fragmento em detalhe. Extensão e contenção, sístole e diástole são procedimentos que ele requisita, ao pensar como quem mergulha no coração das coisas.

A idéia e o fenômeno, como expõe no estudo sobre o trauerspiel, necessitam-se mutuamente, ainda que difiram. Exemplo disso, dos mais ricos, vem a ser o volume do Trabalho das

1 "Desenganos da vida humana metaforicamente". A seguir, transcrevo 0 poema na íntegra: "É a vaidade, Fábio, nesta vida,/ Rosa, que da manhã lisonjeada,/ Púrpuras mil, com ambição dourada, / Airosa rompe, arrasta presumida.// É planta, que de abril favorecida,/ Por mares de soberba desatada,/ Florida galeota empavesada,/ Suca ufana, navega destemida.// É nau enfim, que em breve ligeireza,/ Com presunção de Fênix generosa,/ Galhardias apresta, alentos presa:// Mas ser planta, ser rosa, nau vistosa/ De que importa, se aguarda sem defesa/ Penha a nau, ferro a planta, tarde a rosa?" (Em: Matos, Gregório de. Poemas escolhidos. Seleção, introdução e notas de José Miguel Wisnik. São Paulo: Cultrix, s/d: 321.) 
(Benjamin, Walter. Paris capitale du siècle XIX. Le livre des passages. Trad. de I' allemand par Jean Lacoste d' après l' édition originale établie par Rolf Tiedemann. 3e. ed. Paris: Cerf, 2000.)

(Buck-Morss, Susan. Dialética do olhar. Walter Benjamin e o projeto das passa gens. Trad. Ana Luiza Andrade. Revisão técnica David Lopes da Silva. Belo Horizonte: Ed. UFMG, 1992: 28.)

(Ibid.: 179.) passagens ${ }^{*}$ traduzido para o francês, em 1989, com o título de Paris capital do século XIX. Nele estão editados os diversos cadernos de notas que deixou com amigos e que pouco a pouco vêm sendo publicados, além de alguns outros textos - como o projeto que apresentou ao Instituto de Pesquisas da Escola de Frankfurt. Um estranho fenômeno liga sua obra e sua vida. Cacos, ruínas, fragmentos, numa constante dispersão e recoleção barrocas assinalam um destino de flâneur. 0 mais impressionante é que, à medida que os lemos, uma (ilusória?) sensação de unidade se avizinha. Seus textos urdem uma complexa rede em que o eterno retorno dos elementos, sob recorte e montagem, numa arte plástica da palavra, se oferece como escultura irradiante na qual as idéias cintilam e, de modo (co)movente, desenham o perfil da reflexão ágil, desafiadora e única do pensador.

É assim que, longe de formarem unidades completamente distintas, A origem do drama barroco alemão, Rua de mão únicae Charles Baudelaire, um lírico no auge do capitalismo - para ficarmos com um bloco de conhecidos textos - configuram fragmentos de um estudo cuja totalidade, jamais fechada, foi-se gradativamente elaborando e terminou inacabada, pois o "Passagen-Werk em si não existe - nem sequer uma primeira página e muito menos um esboço do conjunto ${ }^{\prime \prime}$. No entanto, o elo que reúne as partes enovela sutilmente alguns temas privilegiados pelo autor: tempo, história, melancolia e alegoria, tornados mônadas consteladas que se reincorporam de texto a texto.

História, melancolia e alegoria ${ }^{2}$ articulam-se magnificamente em Origem do drama barroco alemão. Por outro lado, tempo, alegoria e cidade revelam-se o emblema de Rua de mão única. E todos esses temas-problema comparecem no estudo sobre Baudelaire. Primeiramente, é bom não esquecer de uma observação inteligente de Pierre Missac* acerca da marca de inconclusão na obra de Benjamin: ou seja, do fato de que ele era portador de um paradoxal projeto de fazer um livro de citações, como negação do livro ou mesmo como realização de um livro

2 Em carta de 5 de março de 1924 dirigida a Gershom Scholem, Benjamin anuncia um projeto em três capítulos que versaria sobre a história, a melancolia e a alegoria. 0 esboço sofrerá alterações, mas, segundo Tiedemann, o editor alemão já deixa entrever a construção definitiva. (Cf. Missac, Pierre. Passagem de Walter Benjamin.Trad. Lília Scorel. São Paulo: Iluminuras, 1998: 168-9.) 
em que apenas usasse o inventário de matéria bruta, de consulta, propício a uma série de metamorfoses nas quais o leitor intervém. Em segundo, é bom lembrar também que, dos três títulos aqui destacados, apesar de anunciarem textos distintos, talvez apenas o primeiro, Origem do drama barroco alemão, merecesse a denominação de livro. 0 segundo, Rua de mão única, escrito e publicado em vida do autor, tem um caráter intencionalmente descontínuo. Nele saltamos da viagem crítica e melancólica através da inflação alemã até as memórias pessoais, passando por sintéticas observações sobre o cotidiano. 0 terceiro volume (na edição brasileira, Obras escolhidas III, na qual não se faz qualquer referência ao fato de que se trata da tradução de um conjunto de fragmentos), Charles Baudelaire, um lírico no auge do capitalismo, vincula-se ao Trabalho das passagens e tem uma crônica de inacabamento a que se refere Jeanne Marie Gagnebin:

Vale a pena lembrar rapidamente a história conturbada da publicação dos ensaios benjaminianos sobre Baudelaire, pois ela testemunha, de maneira exemplar, as dificuldades de toda ordem que Benjamin enfrentou nos seus últimos anos de vida. Essa história também nos previne contra uma interpretação apressada e globalizante que leria nesses textos uma teoria acabada da poesia moderna e da grande cidade, enquanto são partes, importantes, sem dúvida, de uma obra maior que não chegou a se realizar. ${ }^{*}$

Dito um livro idealista, para alguns dos comentadores que nele vêem o "jovem Benjamin", acredito que no estudo sobre o drama barroco já está em exercício a reflexão que, sem nenhum evolucionismo, dispara a maquinaria de sua perquirição, gerando uma interessante e paradoxal "unidade fragmentária" das três "obras". De essencial, a reuni-las, o fato de que o autor jamais abandonou o acervo crítico que Ihe forneceu a descoberta do potencial revolucionário da alegoria, que revisita e reconceitua em pelo menos duas delas. É oportuno aqui retomar a única consideração mais extensa que Benjamin nos dá do que toma por alegoria, já que sua interpretação se distingue de todas as demais a que se refere. Dizendo que ela significa um passo de transgressão ao modelo da arte vista como símbolo, ele avança que, ao contrário daquele, a alegoria

mostra ao observador a facies hippocratica da história como protopaisagem petrificada. A história em tudo o que nela desde 0 início é prematuro, sofrido e malogrado, se exprime num rosto - não, numa caveira. [...] [E]ssa figura, de todas a mais sujeita à
* (Gagnebin, Jeanne-Marie. "Baudelaire, Benjamin e 0 moderno". Op. cit.: 140.) 
* (Benjamin, Walter. Origem do drama barroco alemão. Op. cit.: 188.)

(Ibid.: 199.)

(Ibid.: 220.) natureza, exprime não somente a existência humana em geral, mas, de modo altamente expressivo, e sob a forma de um enigma, a história biográfica de um indivíduo. Nisso consiste o cerne da visão alegórica: a exposição barroca, mundana, da história como história mundial do sofrimento, significativa apenas nos episódios do declínio.

É pelo ganho conceitual do que ele apreende como idéia, e pelo gancho da relação entre alegoria e melancolia, e entre estas e o tempo e a história que sua obra se sustenta enquanto unidade dispersa, parte e todo ao mesmo tempo, tornando-se pouco proveitoso, a meu ver, a seqüenciação entre um Benjamin imaturo e um outro que, depois, teria amadurecido. Seu pensamento, tanto quanto seu método, se realiza no exame e no conflito de formas extremas.

Se, no drama barroco, que transgride as fronteiras do gênero trágico, a história penetra no palco enquanto escrita e está gravada com os caracteres da transitoriedade, dizendo dos riscos da perecibilidade do homem enquanto ser da história vista como natureza*, do mesmo modo os textos de Benjamin, inacabados, repletos de citações, interrompidos por cesuras indispensáveis à ruminação do melancólico, dizem não só dos riscos de um pensamento que se quer formado de paradas e recomeços, mas também da ameaçadora e trágica condição histórica sob a qual o próprio Benjamin viveu e a qual examinou enquanto pensador. Uma condição que se fez corpo de escrita e que, historicizada, se inscreveu e penetrou em sua própria obra, marcada pelo fragmentário, ao fazer-se reflexão sobre o choque e o fragmento e sua (por vezes impossível) relação com a totalidade.

De sua escrita se pode dizer o que ele mesmo propõe acerca da alegoria ocidental: "é uma figura tardia, baseada em ricos conflitos culturais ${ }^{\prime \prime}$. Se, como afirma Benjamin, o drama barroco alemão não recebeu influência dos temas da tragédia antiga, nem da teoria aristotélica dos gêneros, fazendo-se o drama do soberano e da soberania, nele se discute a doutrina extrema do poder do Príncipe. Por extrema ironia histórica, Benjamin também se encontra, ao escrever, sob a mutação de um sentido de soberania, a da República de Weimar, que estenderia, após 1937, seus tentáculos absolutos em versão moderna e aterrorizante.

Objetivando mostrar que, por seu caráter disseminador e histórico, a alegoria, enquanto forma artística, converte "em 
conteúdos de verdade, de caráter filosófico, os conteúdos factuais, de caráter histórico, que estão na raiz de todas as obras significativas ${ }^{\prime \prime}$, 0 ensaísmo de Benjamin se fez em conjuntura com a dobra da própria concepção de história de que falava. Quando estabelece a correlação entre a alegoria barroca e a medieval e as distingue na sua historicidade, Benjamin lança o germe de uma nova maneira de se compreender a modernidade, questão que vai examinar até sua morte. Se a alegoria moderna vincula-se a uma leitura do tempo extremamente diversa da que ocorre nas alegorias medieval e barroca, nela ainda se recuperam traços da alegoria barroca, em seu poder de metamorfose e na ligação com a morte e a soberania numa época de declínio, do mesmo declínio que a obra e a vida de Benjamin irão enfrentar.

Rua de mão única inicia a transferência da reflexão anterior, sobre a alegoria barroca, para a que se debruça sobre a alegoria moderna e sua escrita por fragmento: "Citações em meu trabalho são como salteadores no caminho, que irrompem armados e roubam ao passante a convicção $0^{\prime \prime}$. Nesse texto, o olhar alegórico da modernidade (e sobre ela) toma acento. Nele está a semente da flânérie, da deambulação de uma escrita que pula de um tema a outro e estabelece vínculos influenciados pela visão surrealista da escrita automática. Se em Origem do drama barroco alemão Benjamin entrevê, na alegoria, o espelho da própria construção da história como catástrofe, em Rua de mão única

ele decifra cidades européias como se fossem grandes bibliotecas, em cujas ruas-corredores ia encontrando os palimpsestos, nos quais lia o passado no presente, o presente no passado, o distante no próximo e o próximo no distante. E antes de Borges, insistia na idéia do labirinto. ${ }^{*}$

Rua de mão única foi escrito e publicado paralela e simultaneamente à tese sobre o drama barroco alemão. E podemos dizer que nele a modernidade se revela como um trauerspiel ${ }^{3}$, pois Benjamim a focaliza como época de prazer e de declínio, em que reina a melancolia e na qual o papel de herói está à disposição. A estrutura em fragmentos de Rua de mão única consiste
(Ibid.: 204.)

- (Benjamin, Walter. Rua de mão única. Obras escolhidas II. Op. cit.: 61.)

- (Cf. Köthe, Flávio. Para ler Benjamin. Rio de Janeiro: Francisco Alves, 1976: 29.)

${ }^{3} \mathrm{~A}$ idéia, aqui adaptada, é originalmente empregada por Willi Bolle em Fisiognomia da cidade moderna (São Paulo: EDUSP, 1996: 105). 
(Bolle, Willi. Fisiognomia da cidade moderna. Op. cit.: 112.)

(Missac, Pierre. Walter Benjamin passages. Translated by Shierry Weber $\mathrm{Ni}$ cholsen. Cambridge, Massachusetts: MIT Press, 1995: 89. Missac comenta 0 aspecto de winged speech do aforismo benjaminiano.)

(Ibid.: 90.)

(Sobre isto, há interessante reflexão em Missac, Pierre. Walter Benjamin passages. Op. cit.: 171-2.)

(Gagnebin, Jeanne-Marie "Baudelaire, Benjamin e o moderno". Op. cit.: 160.)

(Benjamin, Walter. "Cervejaria". Em: Rua de mão única. Obras escolhidas II. Op. cit.: 66-7.) numa prática de desmontagem e remontagem, na qual textura e escultura contribuem igualmente para a construção, assim como o desenho da história como cesura e interrupção se clarifica. 0 recurso, que viria a ser usado amplamente na década de 1930 no Trabalho das passagens, faz aí o seu primeiro aparecimento: "preocupado com a persistência de estruturas do Ancien Regime na República de Weimar, Benjamin procura tornar transparentes elementos míticos inerentes ao poder ${ }^{\prime *}$. Em cartas escritas a Hofmannsthal ( 11 de junho de 1925) e Scholem (29 de maio de 1926), durante a composição de Rua de mão única, Benjamin refere-se à obra dizendo que era um trabalho breve, um livro de aforismos, embora em outros momentos rejeitasse o termo. Pierre Missac denomina-o "discurso alado"/*. Num certo sentido, pode-se também interpretar o uso do aforismo por Benjamin como uma espécie de renúncia à ambição de escrever um livro como sendo algo fechado no espaço e no tempo. * Pode-se interpretar Rua de mão única como um éclat. Isto é, ao mesmo tempo explosão e lasca; estilhaço de um corpo que salta com violência, articulando brilho, e, igualmente, o sentido de autonomia de algo que, destacando-se de um todo, realiza-se como fragmento e totalidade, simultaneamente.

Homenagem ao Surrealismo e à revolução russa* e também dedicado a Asia Lascis, assistente de direção de Brecht, com a qual Benjamin se relaciona entre 1924 e 1928 (ela o apresenta a Brecht), Rua de mão única sublinha uma inicial tentativa do autor de articular as esferas política, teórica e estética, com uma forte influência surrealista, através das categorias de tempo, choque e memória. Sobre isto é interessantíssimo o fragmento "Cervejaria", no qual o autor corroía a oposição entre o nacional e o internacional, entre a identidade como algo fixo e portador de essência e a construção discursiva do olhar como constituinte do objeto e da própria subjetividade. Se, como diz Benjamin no fragmento citado, "na mala do marinheiro o cinturão de couro de Hong-Kong está ao lado do panorama de Palermo e de uma foto de moça de Szczecin", e se "a cidade não é visitada, mas comprada" ", resta examinar o que reúne estas "compatibilidades incompatíveis" de elementos não pertinentes entre si.

Acerca da trinca de categorias em jogo - tempo, choque e memória-, lembra Jeanne Marie Gagnebin um trecho que chama de "profético", no qual Benjamin apresenta a escrita de Rua de mão única como "inexoravelmente arrastada para as ruas 
pelos reclames e submetida às brutais heteronomias do caos econômico ${ }^{\prime \prime}$. Quanto ao acento político na obra em questão, seu biógrafo Momme Brodersen* comenta que a decisão de Benjamin de apresentar os aspectos políticos de seu pensamento também se reflete na capa que o autor escolheu para o livro. Feita por Sascha Stone, ela apresenta de imediato a impressão de rapidez, simultaneidade e modernidade. ${ }^{*}$ Quanto ao título, seu biógrafo encontrou, num antigo anúncio da obra, feito quando de seu lançamento (no Literarische Welt, de 25 de maio de 1928), o seguinte comentário do resenhista, Hesse": "a forma do livro é a de uma rua, uma seqüência de casas e lojas cujas janelas são cheias de idéias brilhantes ${ }^{\prime \prime *}$. Os fragmentos de Rua de mão única são uma interpretação do presente, e não uma construção teórica acabada. Benjamin neles relaciona, de maneira inédita, observações pessoais, memórias de infância, viagens e flânérie contrapostas às novas condições de produção da arte e da cultura na modernidade. 0 sentimento do tempo presente, a modernidade como época melancólica e sem heróis, reino de mercadorias, pode ser bem observado no fragmento "Panorama imperial" e no subtítulo "Viagem através da inflação alemã" (números I a XIV), nos quais o mundo alemão durante a República de Weimar é observado e criticado com agudeza." 0 aforismo intitulado "Estas áreas são para alugar" também é um exame inteligente e precursor - que será desenvolvido em trabalhos posteriores do autor - sobre a condição da arte num mundo de mercadorias, sob a égide da propaganda e no qual

[a] "imparcialidade", o "olhar livre" são mentiras, quando não são a expressão totalmente ingênua de chã incompetência. 0 olhar mais essencial hoje, o olhar mercantil, que penetra no coração das coisas, chama-se reclame. Ele desmantela o livre espaço de jogo da contemplação e desloca as coisas para tão perigosamente perto da nossa cara quanto, da tela de cinema, um automóvel, crescendo gigantescamente, vibra em nossa direção.*

Está se elaborando, aqui, a genial observação benjaminiana, feita em "Sobre alguns temas em Baudelaire", de que a modernidade, em seu acelerado processo de modernização, substitui a experiência pela vivência de choque e oferece aos homens 0 espaço nublado da mercadoria.

\footnotetext{
${ }^{4}$ Hermann Hesse foi um dos poucos intelectuais a mostrar um interesse crescente no talento literário de Benjamin quando da publicação de Rua de mão única.
}

(lbid.: 28.)

(Brodersen, Momme. Walter Benjamin, a biography. Transl. by Malcom R. Green and Ingrida Ligers, Ed. by Martina Dervis. London / New York: Verso, 1997.)

(Ibid.: 146.)

- (Cf. Brodersen, Momme. Walter Benjamin, a biogra phy. Op. cit.: 147.)

(Cf. Benjamin, Walter. Rua de mão única. Obras escoIhidas II. Op. cit.: 20-6.)

(Ibid.: 54-5.) 
* Gagnebin, Jeanne Marie. Histoire e narration chez Walter Benjamin. Paris: L' Harmattan, 1994.)
Na especial articulação dos temas que estão sendo examinados, e que Benjamin transforma em imagens dialéticas, a alegoria da face hipocrática da história - destacada no drama barroco em tudo que tem de conturbado - reúne três tempos distintos que, para o crítico, têm um traço de historicidade em comum, já que são momentos de dramática situação do homem em face da soberania e do estado.

Desse modo, entre os três textos em pauta perfazem-se articulações temporais inesperadas, que só a compreensão de história como cesura permite realizar: o século XVII, em que toma acento o drama barroco alemão, convive com o século XIX - em que Baudelaire corrói o conceito de moda e progresso da sociedade burguesa que lhe é contemporânea -, e estes também se intertextualizarão com o século $X X$, no qual Benjamin vive e escreve sob o impacto da República de Weimar. Nos referidos textos, as imagens do tempo e da história não se prestam a uma saga heróica e ufana; antes, estão ameaçadas pela tempestade, pela finitude, pela corrosão, pela melancolia, pelo progresso (e pela inconclusão), tornando-se afinadas com os dois "anjos" a que Benjamin dá estatuto de imagens aladas. Ao fazê-lo, a reflexão de Benjamin aponta para a impotência de um mundo premido pela violência e o choque de uma barbárie que a soberania e/ou o progresso dramaticamente implicam:a face hipocrática e contorcida de nossa humanidade.

Benjamin desenvolve, ao longo de seus textos, desde a Origem do drama barroco alemão, uma conceituação da história como interrupção e cesura, a que já nos referimos, e que foi estudada competentemente por Jeanne Marie Gagnebin, em Narration e histoire chez Walter Benjamin.*

Segundo a autora, a idéia de interrupção e, mais especificamente, a de cesura desempenham no pensamento de Benjamin uma dupla função: através delas ele critica uma concepção trivial da relação histórica (a de causalidade determinista); e, ao mesmo tempo, propõe a intensidade de um encontro súbito entre dois acontecimentos que, colhidos bruscamente, se cristalizam numa significação inédita, reunindo tempos cronologicamente distantes que, examinados em sua diferença, seriam também reveladores de uma inserção histórica distinta.

Isto ocorre, por exemplo, quando Benjamin relaciona o conceito de história com duas alegorias pictóricas: a Melencolia I, de Albert Dürer (1528, e cujo algarismo faz parte do título, já 
que ele compôs um tríptico) e o Angelus novus, de Paul Klee (1920).

Em 1921, Benjamin adquire uma gravura de Klee que se tornaria famosa: o Angelus novus, motivo central da nona tese ${ }^{*}$ sobre a filosofia da história. A história dos vencidos, diga-se de passagem, pois esta é a que a Benjamin escreve, mesmo tratando de temas diversos, como o drama barroco, a poesia baudelairiana, o surrealismo e a metrópole moderna. Considera ele em sua nona tese:

Existe um quadro de Klee intitulado Angelus novus. Nele está representado um anjo, que parece na iminência de afastar-se de algo em que crava seu olhar. Seus olhos estão arregalados, sua boca está aberta e suas asas estão estendidas. 0 anjo da história deve parecer assim. Ele tem o seu rosto voltado para o passado. Onde diante de nós aparece uma cadeia de acontecimentos, ele enxerga uma única catástrofe, que sem cessar amontoa escombros sobre escombros e os arremessa a seus pés. Ele bem gostaria de demorar-se, acordar os mortos e juntar os destroços. Mas do paraíso sopra uma tempestade que se emaranha em suas asas e é tão forte que o anjo não pode mais fechá-las. Esta tempestade 0 impele irresistivelmente para o futuro, ao qual volta as costas, enquanto o amontoado de escombros diante dele cresce até 0 céu. 0 que nós chamamos de progresso é essa tempestade. *

Antes de observarmos mais atentamente o fragmento em destaque, sublinhe-se que o itinerário do pensamento benjaminiano sobre a história como cesura e interrupção* teve seu primeiro passo no exame de uma outra alegoria, a de Dürer, mencionada na Origem do drama barroco alemão*. Nas artes visuais, desde a Idade Média a melancolia determina uma iconografia à parte*. Estudos tornados clássicos, como o de Panofsky sobre Dürer, de 1943, tomam a obra deste, em especial a que é referida por Benjamin, como a que melhor ilustra o caráter enigmático do humor melancólico.

Na gravura de Dürer, um anjo pensativo se faz acompanhar de um cão e de uma esfera, entre outros elementos. Susana Kampff Lages, em Walter Benjamin, tradução \& melancolia, observa que os elementos dispersos na gravura - o livro, a esfera, a bolsa de dinheiro, o compasso, a escada, a balança, a ampulheta, o sino, o cão, o putto, o morcego, o arco-íris, o quadrado mágico, as chaves e as ferramentas - são objetos que pertencem a uma iconografia tradicional, mas que, nesta, parecem adquirir um novo significado*.
(Benjamin, Walter. "Sobre o conceito de história". Em: Magia e técnica, arte e política. Obras escolhidas I. Trad. Sérgio Paulo Rouanet. Pref. Jeanne Marie Gagnebin. São Paulo: Brasiliense, 1985.)

(Ibid.: 226.)

(Gagnebin, Jeanne Marie. Histoire e narration chez Walter Benjamin. Op. cit.: 146-57.)

(Op. cit.: 174-80.)

- (Cf. Lages, Susana Kampff. Walter Benjamin, tradução \& melancolia. São Paulo: EdUSP, 2002: 38.)

(Ibid.: 48. 
(Ibid.)

' (Benjamin, Walter. Origem do drama barroco alemão. Op. cit.: 164.)

\section{Diz ela:}

E para se determinar o que seria este "outro significado", é indispensável a participação ativa de outro leitor: o observador, o leitor da gravura. Aliás, há na gravura, não apenas um livro (aquele que repousa, fechado, sobre o colo da alada Melancolia), mas um outro livro - que repousa aberto e receptivo à incisiva ação (com intenção de escrever ou inscrever, gravar algo) do igualmente alado putto. Não apenas uma figura alada, mas duas: a figura de mulher alada acompanhada pela figura do putto. Panofsky contrapõe a atividade do putto à inatividade da Melancolia, interpretando-o como o emblema da Prática (der Brauch), que age impulsivamente, como oposto à Teoria, à Arte, die Kunst, que pensa mas é incapaz de agir. [...]. Por outro lado, como enfatiza Agamben, ambas as figuras remetem à tradição da representação do fantasma sob a forma de entidade erótica dotada de asas.”

Benjamin privilegia o fato de que, nesta gravura, que para ele antecipa o Barroco, "o saber obtido pela ruminação e a ciência obtida pela pesquisa se fundiram tão intimamente como no homem do Barroco. A Renascença investiga o universo, e o Barroco, as bibliotecas. Sua meditação tem o livro como correIato ${ }^{\prime \prime *}$. Não Ihe escapou, portanto, a representação das relações entre as figuras aladas e o livro, entre a ação e a reflexão, entre a melancolia e o ruminar do pensamento. Benjamin lê, na gravura, o anjo, o cão e a esfera como protagonistas de um drama que se encena na cidadela do pensamento de um saturnino que medita sobre a tristeza de um mundo de príncipes e de mártires. $E$, não por último, ressalta que, tanto na gravura do renascentista Dürer como para o Barroco (e para ele, Benjamin, por que não dizer) a relação entre o livro, o anjo e o putto (como na versão de Panofsky) é mediada pela melancolia, na qual o "Livro da Natureza" e o "Livro dos Tempos" são objetos de meditação barroca. "É consistente com este conceito que em torno do personagem de Albert Dürer, na Melencolia, estejam dispersos no chão objetos da vida ativa, sem qualquer serventia, como objetos de ruminação". *

No quadro de Klee, o anjo se volta para trás, tentando escapar da tempestade do progresso que sopra do paraíso da sociedade de mercado, em que o fetiche faz do tempo algo homogêneo e vazio. Benjamin encontra em Baudelaire o campo privilegiado para levar adiante a reflexão sobre o sentido do tempo e da história. Na evocação do spleen do olhar saturnino do flâneur que compõe com a cidade o duelo da lírica tornada "fantástica 
esgrima", os trapeiros, as prostitutas, as lésbicas e o poeta são o novo anjo; do mesmo modo, o Ângelus novus, de Klee, é a sua representação.

São eles as máscaras de um artista que encontrava na escrita a contrapelo a capacidade de transitar pela modernidade e pelo choque, numa forma de escrita sombreada com a luz claroescura do véu da melancolia. Pois (em Baudelaire, e em Benjamin), "[t]rapeiro ou poeta - a escória diz respeito a ambos: solitários, ambos, realizam seu negócio nas horas em que os burgueses se entregam ao sono ${ }^{\prime \prime *}$.

Captando o sentimento de transitoriedade, o lapso, o lixo e o resíduo da reificação burguesa da arte e do homem tornados mercadoria num mundo de fetichismo do consumo, a arte de Baudelaire é, para Benjamin, o anúncio de uma historicidade que adensa o sentimento agudo de efemeridade que já caracterizara - como vimos em seus textos - épocas do passado, em particular a idade barroca:

Mas essa consciência opunha então a eternidade divina à fugacidade humana, num horizonte teológico ainda estável. 0 que é próprio da modernidade é o desmoronamento desse horizonte e, conseqüentemente, a falta de um pólo duradouro que servia, outrora, de razão e de consolo do efêmero. A cidade moderna não é um lugar de passagem em oposição à perenidade da cidade de Deus mas, na sua mais profana e material natureza, o palco isolado de transformações incessantes que revelam sua fragilidade: " $A$ forma de uma cidade/ Muda mais rápido - ai de mim! - que o coração de ummortal".

Num mundo de objetos e seres em declínio, mercadorias no bazar da economia capitalista da Paris capital do século XIX e da Weimar túmulo do século XX, a desvalorização se intensifica e promove um processo de corrosão das coisas, dos seres e do tempo. Este modo de produção caracteriza, segundo Benjamin, um dos eixos da modernidade e altera-Ihe a sensibilidade que Ihe é contemporânea, que se torna afeita ao choque do qual se protege, desenvolvendo capacidades que provocam perdas e ganhos para a vida social.

Se, para o autor de Origem do drama barroco alemão, o soberano representa a história*, a atividade crítica que empreende em seus trabalhos transforma-os (o soberano e a história) em escrita e forma de reflexão sobre a soberania e a arte modernas. Focalizando-as como categorias estéticas, enlaça-as ao passado e ao presente, com um olhar que faz explodir, sempre de modo
(Benjamin, Walter. "Paris do segundo império". Em: Charles Baudelaire, um lírico no auge do capitalismo. Obras escolhidas III. Trad. José Carlos Martins Barbosa e Hemerson Alves Baptista. 2a . ed. São Paulo: Brasiliense, 1991: 78-9.)

- (Gagnebin, Jeanne-Marie. "Baudelaire, Benjamin e o moderno". Op. cit.: 150.)

(Benjamin, Walter. Origem do drama barroco alemão. Op. cit.: 88. ) 
- (Matos, Olgária C. F. 0 iluminismo visionário: Benjamin, leitor de Descartes e Kant. São Paulo: Brasiliense, 1993.) surpreendente, vários sentidos de soberania e o êxtase das formas que caracterizou a modernidade artística.

Pelo menos dois sentidos de soberania são conhecidos de seus leitores: o que prevaleceu até o século XVII e, neste, sofreu radical mudança, especialmente com os tratados de Hobbes sobre a monarquia absoluta como forma de conter as guerras religiosas; e o que se privilegia nas primeiras décadas do século $X X$, quando Benjamin elabora seu pensamento e novas formas de absolutismo tentacular se engendram no nazi-fascismo.

Por sob as páginas em que trata do trauerspiel do barroco alemão, já perpassa e se intensifica o drama de uma Alemanha que viria a abalar os alicerces da modernidade e cuja presença será mais forte ainda em Rua de mão única. Sobre esta questão, Olgária Matos, em 0 iluminismo visionário*, diz que Benjamin publica ${ }^{5}$ Origem do drama barroco alemão - o do século XVII em 1928, preocupado com a inflação, o nacionalismo e outros aspectos da crise alemã, e que escreve Paris capital do século XIX em 1934, pressentindo o desmoronamento da Frente Popular de 1936 na França. Completa a autora: "É desse sonho que o século $X X$ deve despertar ${ }^{\prime \prime *}$.

Despertamos?

Por um lado, o sucesso da obra de Benjamin revela a importância do que a modernidade e sua investigação, pelo autor, nos legou. Mas, por outro, sua morte prematura, pelo suicídio em face da iminência da prisão por oficiais da Gestapo, assinala uma outra face, terrível, da mesma modernidade, inacabada ainda, e desencadeadora de destruição e horror. A importância de seu pensamento não cessa de crescer e de se estender. Por mais diversificados que tenham sido seus temas e os interesses que manifesta, um ponto em comum os reúne: a relação entre arte, sociedade e história. Num tempo de declínio e penúria, em que nunca a humanidade foi tão rica e tão pobre, uma de suas propostas - a de que não há um documento de cultura que não seja também um documento de barbárie - ecoa dramaticamente. Talvez a melhor homenagem que se possa prestar ao pensador seja a de sublinhar, para que seja levada adiante, a necessidade de uma (re)investigação delicada e instigante das relações entre a arte e a sociedade, mediadas pela imagem da história como metáfora da soberania.

\footnotetext{
${ }^{5} 0$ livro foi esboçado em 1916, escrito em 1925 e publicado em 1928.
} 


\section{Lucia Helena}

Doutorou-se em 1983 pela UFRJ, na área de Teoria da Literatura. Fez pós-doutorado em 1989, em Literatura Comparada nos Estados Unidos, na Brown University. Ministra, com relativa constância, cursos em Universidades norte-americanas e tem atuado como conferencista nos Estados Unidos e na Europa. Atualmente é professora Titular da UFF e pesquisadora 1-A do CN Pq. Dentre suas publicações, destacam-se, com prêmio nacional, Totens e tabus da modernidade brasileira; e Nem musa, nem medusa: itinerários da escrita em Clarice Lispector.

\section{Resumo}

Este trabalho estuda as imagens dialéticas - história, tempo, alegoria e melancolia - concebidas por Walter Benjamin. Propõe-se que elas são formas de repensar a história como cesura e interrupção, e não mais como uma evolução linear e positivista do tempo. 0 artigo, do mesmo modo, focaliza as inter-relações entre elas, concebendo-as como categorias fundamentais para uma nova abordagem filosófica dos elos entre arte e sociedade.

\section{Abstract}

This work studies the dialectical images - history, time, allegory and melancholy, weaved by Walter Benjamin. We propose that they are a way of rethinking history as interruption and fragmentation, and not anymore under a linear and positivist perception of the evolution of time. The article also takes into consideration their inter-relationships, which allows us to focus on them as fundamental categories to provide a new philosophical approach of the links between art and society.

\section{Résumé}

Ce travail étude les images dialectiques - histoire, temps, allégorie et mélancolie - conçues par Walter Benjamin. On les comprends comme un moyen de réfléchir sur le phénomene historique observé comme césure et interruption et, non plus, comme I'evolution positiviste et linéaire du temps. L'article considère, aussi, les relations entre ces images vues comme catégories fonda mentales d'une nouvelle conception philosophique des traits d'union entre I'art et societé.
Palavras-chave

alegoria

história

imagens dialéticas

melancolia

modernidade

Walter Benjamin

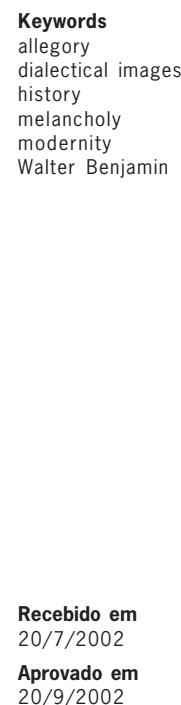

Keywords

dialectical images

history

modernity

Walter Benjamin

Aprovado em 20/9/2002 